\title{
A-Kinase Anchor Protein SPHKAP
}

National Cancer Institute

\section{Source}

National Cancer Institute. A-Kinase Anchor Protein SPHKAP. NCI Thesaurus. Code C127887.

A-kinase anchor protein SPHKAP (1700 aa, 186 kDa) is encoded by the human SPHKAP gene. This protein is involved in the regulation of signaling mediated by protein kinase A and by sphing osine kinase 1 . 